\title{
KEY DETERMINANTS INFLUENCING THE HEALTH LITERACY OF PREGNANT WOMEN IN THE CZECH REPUBLIC KLJUČNE DETERMINANTE, KI VPLIVAJO NA ZDRAVSTVENO PISMENOST NOSEČNIC NA ČEŠKEM
}

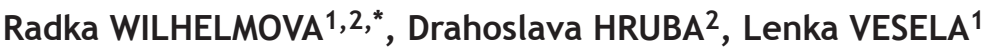 \\ ${ }^{1}$ Masaryk University, Faculty of Medicine, Department of Midwifery, Komenskeho nam. 2, 66243 Brno, Czech Republic \\ ${ }^{2}$ Masaryk University, Faculty of Medicine, Department of Preventive Medicine, Kamenice 5, 62500 Brno, Czech Republic
}

\section{ABSTRACT}

Keywords:

health literacy, pregnancy, prenatal care, primary prevention, midwife
Background. Health literacy is a critical determinant of women's and children's health and therefore has immense consequences for the health of society as well. Evidence from epidemiological, clinical and experimental studies indicates that unhealthy lifestyles and risky behavioural habits of parents before conception and during pregnancy influence the etiology of various health defects. Decreasing primary risk factors, practicing physical wellness, monitoring physiological markers and preparing for labour, breastfeeding and newborn care should be the main parental responsibilities during the prenatal period.

Methods. Our study focused on specifying the main determinants of health literacy among 360 pregnant Czech women by using an anonymous questionnaire and selected anthropometric data of mothers. The criteria for study participation produced a sample representing $1.41 \%$ of Czech women in labour during a given 2012 reference period.

Results. Despite quite adequate knowledge of both risks and supporting factors for pregnancy and foetal development, the lifestyles of a majority of the women surveyed were far from optimum: only $30 \%$ reported good dietary and physical activity habits, $24 \%$ were active or passive smokers and one third of the women occasionally drank alcohol, more often among those who were university educated.

Conclusion. Our results have confirmed previously published data noting that health literacy and a healthier lifestyle of pregnant women are associated with a higher level of education (except for alcohol drinking) and with contact with a midwife (in some examined parameters) in prenatal courses.

Uvod. Zdravstvena pismenost je ključna determinanta zdravja žensk in otrok, ki ima ogromne posledice tudi na zdravje družbe. Dokazi iz epidemioloških, kliničnih in eksperimentalnih študij kažejo, da nezdravi življenjski slogi ter tvegano vedenje staršev pred zanositvijo in med nosečnostjo vplivajo na etiologijo različnih zdravstvenih okvar. Zmanjševanje dejavnikov tveganja, skrb za fizično dobro počutje, spremljanje fizioloških markerjev ter priprava na porod, dojenje in nego novorojenčka bi morali biti glavna odgovornost staršev $v$ predporodnem obdobju.

Metode. Naša študija je bila namenjena določitvi glavnih determinant zdravstvene pismenosti med 360 češkimi nosečnicami s pomočjo anonimnega vprašalnika in izbranih antropometričnih podatkov o materah. $\mathrm{Na}$ podlagi meril za sodelovanje $v$ študiji je bil izbran vzorec, ki je predstavljal 1,41 \% nosečih žensk na Češkem v zadevnem obdobju leta 2012.

Rezultati. Kljub dokaj dobremu poznavanju tveganj in podpornih dejavnikov za nosečnost in razvoj zarodka so se življenjski slogi večine žensk, vključenih v raziskavo, močno razlikovali od optimalnih: samo $30 \%$ jih je poročalo o dobrih prehranskih navadah in telesni aktivnosti, $24 \%$ je bilo aktivnih ali pasivnih kadilk, ena tretjina žensk je občasno pila alkohol, pogosteje univerzitetno izobražene.

Zaključki. Naši rezultati so potrdili predhodno objavljene podatke, ki kažejo, da sta zdravstvena pismenost in bolj zdrav življenjski slog nosečnic povezana z višjo stopnjo izobrazbe (razen pitja alkohola) in stikom z babico (pri nekaterih proučenih parametrih) na predporodnih tečajih. 


\section{INTRODUCTION}

The experience of pregnancy and labour is a significant factor in the global development of both women and children. Recent research results affirm that the future health of an individual is influenced during the early prenatal period. Sources considering epigenetical mechanisms specifically refer to the preconceptional influence resulting from gene environment interactions $(1,2)$.

Prenatally, a mother positively or negatively determines both the physical and mental health of her child through her decisions and behaviour, which in turn affect her general health conditions later in life. It was recently confirmed that an unfavourable prenatal environment could facilitate vulnerability to cardiovascular and metabolic diseases, which are presently at near epidemic levels among the general population $(3,4)$.

When efficiently utilised, the health-care system can significantly eliminate risks for the mother and child and encourage practices that protect the woman's health and the child's capacity for development. In the Czech Republic, a long history of high levels of prenatal and neonatal care has resulted in low perinatal mortality and morbidity. On the other hand, the prevalence of low-birth-weight newborns has increased significantly from $5 \%$ to $8 \%$ (5). The Czech system of preventive observations by obstetricians in physiological pregnancies uses the officially recommended and unified secondary prevention methods at one-month intervals: monitoring of anthropometric parameters, blood pressure and kidney functions and ultrasound examination. Care oriented towards primary prevention is neither adequate nor effective. Current prenatal care recommends extra examinations for women with physiological pregnancy, and it faces the risk of overmedicalisation. Prenatal care provided by a midwife is not covered by any health insurance in the Czech Republic.

Pregnant women can be exposed to many physical and psychological burdens as well as sources of stress, fear and anxiety. Too many women deal with this stress by smoking, consuming alcohol and eating inappropriate foods, which are recognised risk factors for worst-case pregnancy outcomes. Alcohol and smoking are considered to be preventable risk factors for human reproduction with no safe threshold, human neuro-teratogens $(6,7)$. However, many prenatal care providers in the Czech Republic do not ask about this risk behaviour and some of them even tolerate it. Questions about nutrition, physical activity, stress and occupational hazard exposure are also not included into the routine treatment schedule of many prenatal care providers. They do not offer professional advice for promoting health changes either.

One recommended technique for decreasing the levels of prenatal anxiety and stress is aerobic exercise, which has a wide spectrum of additional benefits: better oxygenation both for mother and foetal tissues, improves mobility and better coordination as a suitable preparation for labour and birth and shortens active phase of labour. Physical activity enhances the capacity to deal with everyday issues related to stress and unexpected situations, and the risk of depression after delivery is lower (8). Adequate activity has no negative impact on a newborn's weight. Women involved with special pregnancy exercise programs had significantly higher life wellbeing scores (9).

According to the experiences reported in some other countries, a new approach to prenatal care is "Group care pregnancy", where an individual check-up is replaced by a longer group session. The basic prenatal examination is accompanied by education, sharing of personal experiences and discussions with a midwife. The Dutch model incorporates somatical and psycho-social needs, and support involves focused attention on a woman's individuality, and the level of responsibility for women's health is increased (10). This model typifies a complex type of care that, when practiced, supports a healthy pregnancy process (11). In the 1970s, a similar model was successfully implemented in daily practice in Sweden and resulted in positive lifestyle changes for women and an overall improvement of family well-being (12). Attention is currently focused even on the preconceptional period, when the health problems of both potential parents should be identified and treated (13).

This new point of view offers a new role for midwives: they can provide information to expectant parents about a healthy lifestyle and the detrimental factors that could negatively influence healthy foetal development and potential and try to help with changes. The midwives can also prepare the couple for labour, the postnatal period, breastfeeding and parenthood. This new trend includes focus on perinatal outcomes along with the woman's prenatal care and the psychosocial needs of women's and children's health not only during pregnancy but also after delivery and throughout their lifetimes as well $(14,15)$. Evidence about increased smoking, alcohol consumption, malnutrition and hypoactivity, especially among young women, indicate that primary prevention should be a part of standard prenatal care (16-18). Participation in primary prevention lessons is an opportunity for a woman to deal with the changes associated with her lifestyle and expectations regarding pregnancy, labour and motherhood; all of this can be a potential source of anxiety and stress. Educational intervention should include the documentation of positive experiences, the dissemination of pregnancyrelated information (including reproductive process physiology) and the strengthening of faith in individual abilities $(19,20)$. In many countries, including the Czech Republic, there is an increasing interest in "schools for mothers". Unfortunately, the majority of such lessons are offered as an additional, self-paid service of standard secondary prevention, without officially unified and supervised content. This education is not available for lower-income women, who are usually undereducated and are more likely to have adopted an unhealthy lifestyle. Voluntary courses for pregnant women, managed by midwives, are oriented towards preparation for delivery, breastfeeding and newborn care, but they do not yet include lifestyle factors. The fact that pregnancy may be the new source of stress for some women, who therefore need special psychological support, is also ignored $(21,22)$. 
Our survey goals were to determine the current health literacy of pregnant women (i.e. their awareness of critical and protective procedures, the risk factors in their lifestyles and the changes they made during pregnancy) and to identify the main determining factors of health literacy (education, parity, place of residence and participation in prenatal courses).

\section{METHODS AND SAMPLE}

A retrospective anonymous questionnaire and a data analysis, collected from July to October 2012, were used. We created a random and proportional sample of women. The primary sample included the 108,000 single babies born in 2011 in Czech hospitals. The second basic sample included the approximately 25,000 single babies born during the quarter when our study was organised. According to these data, the number of participants for our study was established at 540 women ( $2 \%$ of the second basic sample). Five of a total of fourteen Czech districts were chosen by random selection and the particular maternity hospitals in each district were chosen in the same manner. To keep the proportionality of the sample, the number of participating women from each individual clinic was related to the annual/quarterly number of newborns. Women were contacted during the postpartum period. Of the 540 women contacted, a total 393 returned the completed questionnaire (response rate was $72.77 \%$ ), of which 33 had to be excluded due to incomplete data. The final sample thus consisted of 360 women representing $1.41 \%$ of women who had given birth during the study period.

All of the women participating in the study signed an informed consent form and an agreement with the Ethics Committee of University Hospital, Faculty of Medicine, Masaryk University. Fully trained medical staff collected the data.

The main sample characteristics are shown in Table 1. There was a nearly proportional rate of primiparous and multiparous women as well as those with university and high school education; one fifth had only a basic level of education. The level of education was the marker of socioeconomic status. The average age was 30.5 years (median = 31). In terms of parity and age (in comparison with statistical data for the (zech Republic), it is possible to consider the sample as representative. The majority (81\%) gave birth vaginally; $19 \%$ had a Caesarean section. Twice as many participants lived in towns as in villages.

The structure of the questionnaire was based on the Health Promotion Model (23) and on certain items from the standardised questionnaire used in the ELSPAC (European Longitudinal Study of Pregnancy and Childhood) (24). In addition to demographic data, particular blocks of questions were oriented towards factors important for a woman's health and the healthy development of the foetus during pregnancy. These blocks of questions covered both the woman's knowledge and her behaviour (dietary habits, time and type of active physical exercise, body weight and weight gain during pregnancy, smoking, alcohol consumption, il- licit drug use and emotional challenges). A dietary habits index with 10 questions and 32 possible answers (questions focused on the frequency of intake of protective and risk foods) was created, and for each correct answer (according to the food pyramid), one point was counted. Index distribution values ranged from 0 (the worst habits) to 10 (the best habits), index distribution: median $=6$. A risk factors awareness index was created with values ranging from 0 to 21 , index distribution: median $=18$. A Likert scale was used to evaluate the feeling of stress during pregnancy and the postpartum period. Self-reported data were not objectively confirmed, with the exception of BMI and weight gain. The questionnaire was completed with data from obstetrician's protocols and included weight and height before pregnancy, weight gain during pregnancy, the form of delivery and newborn status.

Pearson's x2 (chi-square) test and the ANOVA variance analysis were used to evaluate differences between groups with (a) varied educational levels and (b) frequency of participation in prenatal lessons with midwives; the acceptable value for significance was $p \leq 0.05$, sampling error $5.4 \%$.

Table 1. The characteristic of the sample.

\begin{tabular}{|c|c|c|c|}
\hline \multicolumn{2}{|l|}{ Item } & $\mathbf{N}$ & $\%$ \\
\hline \multicolumn{2}{|c|}{ Number of participants } & 360 & 100 \\
\hline Age & $\begin{array}{l}\text { Average } \\
\text { Median }\end{array}$ & \multicolumn{2}{|c|}{$\begin{array}{c}30.5 y \\
31 y\end{array}$} \\
\hline Education & $\begin{array}{l}\text { Basic } \\
\text { High school } \\
\text { University }\end{array}$ & $\begin{array}{c}69 \\
145 \\
146\end{array}$ & $\begin{array}{l}19.1 \\
40.3 \\
40.6\end{array}$ \\
\hline Residence & $\begin{array}{l}\text { Town } \\
\text { Village }\end{array}$ & $\begin{array}{l}259 \\
101\end{array}$ & $\begin{array}{l}71.9 \\
28.1\end{array}$ \\
\hline Parity & $\begin{array}{l}\text { Primipara } \\
\text { Secundipara } \\
\text { Multipara }\end{array}$ & $\begin{array}{c}178 \\
146 \\
36\end{array}$ & $\begin{array}{l}49.4 \\
40.6 \\
10.0\end{array}$ \\
\hline Smoking & $\begin{array}{l}\text { Never } \\
\text { Former } \\
\text { Current }\end{array}$ & $\begin{array}{c}230 \\
109 \\
22\end{array}$ & $\begin{array}{c}63.6 \\
30.0 \\
6.1\end{array}$ \\
\hline \multicolumn{2}{|c|}{ Alcohol in pregnancy (occasionally) } & 112 & 31.1 \\
\hline Illicit drugs & $\begin{array}{l}\text { Never } \\
\text { Former } \\
\text { Current }\end{array}$ & $\begin{array}{c}299 \\
32 \\
29\end{array}$ & $\begin{array}{c}83.0 \\
8.9 \\
8.1\end{array}$ \\
\hline
\end{tabular}

\section{RESULTS}

The majority of participants had a revealing family health history. The most frequent disease was hypertension (in $51 \%$ of families), $40 \%$ had diabetes mellitus in the family, $30 \%$ of families had atopy and $60 \%$ reported a background of smokers within their family of origin. More than one half of participants (55\%) reported positive unhealthy personal histories: allergies, asthma, recurrent urinary tract infections and anaemia were among the most frequent issues. Nearly two thirds (62\%) reported gynaecological problems including repeated gynaecological inflammation, spontaneous abortion and menstrual cycle problems. The 
interruption of a previous pregnancy was reported by $12 \%$. Nearly two thirds (64\%) used hormonal contraception.

The body mass index (BMI) values of the surveyed women at the beginning of pregnancy reflected a Gaussian curve distribution. The average BMI was inversely related to the level of education and place of residence; see Table 2. More participants with the lowest level of education were overweight or obese before pregnancy (BMI 25.0 and higher) compared to those with a university education (40\% vs. $24 \%$ respectively, $\mathrm{p}<0.001$ ). Women living in villages had a BMI of 25.0 and higher more often than women living in towns (35\% in villages vs. $24 \%$ in towns, $p=0.006)$.

Table 2. Average BMI before pregnancy.

\begin{tabular}{lccc}
\hline & N & BMI Mean & Std. deviation \\
\hline Education: & & & \\
Basic & 69 & 24.5 & 4.6 \\
High school & 145 & 23.2 & 4.5 \\
University & 146 & 22.8 & 3.4 \\
Residence: & & & \\
Town & 259 & 22.9 & 4.0 \\
Village & 101 & 24.2 & 4.5 \\
Total & 360 & 23.3 & 4.2 \\
\hline
\end{tabular}

The average weight gain was $13.4 \mathrm{~kg}$. The highest prevalence of low, optimal and high weight gain is presented in Table 3. More women with the lowest education had higher (more than $15 \mathrm{~kg}$ ) weight gain (36\% vs. $23 \%$ women with university education, $p=0.005)$. A tendency towards higher weight gain was found among primiparous women (35\% vs. $28 \%$ multiparous women) and among women living in villages ( $35 \%$ vs. $30 \%$ in towns).

$\mathrm{BMI}$ and pregnancy weight gain were influenced by dietary habits; better dietary habits (with higher index value) lowered the first-input BMI of women and their pregnancy weight gain to the recommended optimal range $(p<0.001$; $p=0.021$ respectively).

Half of the participants (50\%) reported some preconceptional preparation; 25\% six months or more. Preconceptional preparation was reported more often by primiparous and women with higher education than multiparous and women with lower education. A majority of them considered the omission of contraceptive pills to be a type of preparation for pregnancy.

Prenatal preparation lessons were attended by $39 \%$ of respondents; $17 \%$ attended only a one-time course (focused on information about the labour process and breastfeed-

Table 3. Education, place of residence, parity and weight gain in pregnancy.

\begin{tabular}{|c|c|c|c|c|c|}
\hline & \multirow{2}{*}{$\begin{array}{c}\text { Count } \\
\text { Percent* }\end{array}$} & \multicolumn{4}{|c|}{ Weight gain } \\
\hline & & Suboptimal & Optimal & High & Total \\
\hline \multicolumn{6}{|l|}{ Education: } \\
\hline Basic & $\begin{array}{l}N \\
\%\end{array}$ & $\begin{array}{c}12 \\
16.7\end{array}$ & $\begin{array}{c}32 \\
47.0\end{array}$ & $\begin{array}{c}25 \\
36.4\end{array}$ & $\begin{array}{c}69 \\
100.0\end{array}$ \\
\hline High school & $\begin{array}{l}\mathrm{N} \\
\%\end{array}$ & $\begin{array}{l}11 \\
7.6\end{array}$ & $\begin{array}{c}83 \\
57.2\end{array}$ & $\begin{array}{c}51 \\
35.2\end{array}$ & $\begin{array}{c}145 \\
100.0\end{array}$ \\
\hline University & $\begin{array}{l}\mathrm{N} \\
\%\end{array}$ & $\begin{array}{c}20 \\
14.0\end{array}$ & $\begin{array}{c}91 \\
62.2\end{array}$ & $\begin{array}{c}35 \\
23.8\end{array}$ & $\begin{array}{c}146 \\
100.0\end{array}$ \\
\hline Total & $\begin{array}{l}N \\
\%\end{array}$ & $\begin{array}{c}43 \\
11.9\end{array}$ & $\begin{array}{l}207 \\
57.3\end{array}$ & $\begin{array}{c}110 \\
30.8\end{array}$ & $\begin{array}{c}360 \\
100.0\end{array}$ \\
\hline \multicolumn{6}{|l|}{ Residence: } \\
\hline Town & $\begin{array}{l}N \\
\%\end{array}$ & $\begin{array}{c}32 \\
12.2\end{array}$ & $\begin{array}{c}152 \\
58.8\end{array}$ & $\begin{array}{c}75 \\
29.0\end{array}$ & $\begin{array}{c}259 \\
100.0\end{array}$ \\
\hline Village & $\begin{array}{l}\mathrm{N} \\
\%\end{array}$ & $\begin{array}{c}11 \\
11.3\end{array}$ & $\begin{array}{c}54 \\
53.6\end{array}$ & $\begin{array}{c}36 \\
35.1\end{array}$ & $\begin{array}{c}101 \\
100.0\end{array}$ \\
\hline Total & $\begin{array}{l}N \\
\%\end{array}$ & $\begin{array}{c}43 \\
11.9\end{array}$ & $\begin{array}{l}206 \\
57.4\end{array}$ & $\begin{array}{c}111 \\
30.7\end{array}$ & $\begin{array}{c}360 \\
100.0\end{array}$ \\
\hline \multicolumn{6}{|l|}{ Parity: } \\
\hline Primipara & $\begin{array}{l}\mathrm{N} \\
\%\end{array}$ & $\begin{array}{c}21 \\
11.9\end{array}$ & $\begin{array}{c}95 \\
53.4\end{array}$ & $\begin{array}{c}62 \\
34.7\end{array}$ & $\begin{array}{c}178 \\
100.0\end{array}$ \\
\hline Secundipara & $\begin{array}{l}\mathrm{N} \\
\%\end{array}$ & $\begin{array}{c}18 \\
12.5\end{array}$ & $\begin{array}{c}89 \\
61.1\end{array}$ & $\begin{array}{c}39 \\
26.4\end{array}$ & $\begin{array}{c}146 \\
100.0\end{array}$ \\
\hline Multipara & $\begin{array}{l}\mathrm{N} \\
\%\end{array}$ & $\begin{array}{c}3 \\
8.8\end{array}$ & $\begin{array}{c}22 \\
61.8\end{array}$ & $\begin{array}{c}11 \\
29.4\end{array}$ & $\begin{array}{c}36 \\
100.0\end{array}$ \\
\hline Total & $\begin{array}{l}N \\
\%\end{array}$ & $\begin{array}{c}42 \\
11.9\end{array}$ & $\begin{array}{l}206 \\
57.3\end{array}$ & $\begin{array}{c}112 \\
30.8\end{array}$ & $\begin{array}{c}360 \\
100.0\end{array}$ \\
\hline
\end{tabular}

* Row percentages presented 
ing); $21 \%$ attended only a couple of theoretical lessons and $62 \%$ completed both theory lessons and exercise and practical skills (on average 10 lessons focused on pregnancy, labour, puerperium, infant care and breastfeeding). In most cases, lessons were led by midwives (96\%) with a bachelor's education. In $4 \%$ of cases, the courses were led by a doula (an informed nonmedical person who accompanies and emotionally supports the pregnant woman but who must not interfere with the competencies of a midwife). Factors determining the participation in prenatal courses attendance were mainly contact with a midwife during previous pregnancy $(p<0.001)$, preconceptional preparation $(p<0.001)$, a higher level of education ( $p$ $<0.001)$ and primiparity $(p<0.001)$. Place of residence was not a determining factor $(p=0.089)$. Determinants of prenatal course visitation are shown in Table 4.

Table 4. Determinants of prenatal course visitations.

\begin{tabular}{|c|c|c|c|c|}
\hline & \multirow{2}{*}{$\begin{array}{c}\text { Count } \\
\text { Percent* }\end{array}$} & \multicolumn{3}{|c|}{ Attendance of prenatal course } \\
\hline & & Yes & No & Total \\
\hline \multicolumn{5}{|l|}{ Education: } \\
\hline Basic & $\begin{array}{l}\mathrm{N} \\
\%\end{array}$ & $\begin{array}{c}9 \\
13.0\end{array}$ & $\begin{array}{c}60 \\
87.0\end{array}$ & $\begin{array}{c}69 \\
100.0\end{array}$ \\
\hline High school & $\begin{array}{l}\mathrm{N} \\
\%\end{array}$ & $\begin{array}{c}54 \\
37.2\end{array}$ & $\begin{array}{c}91 \\
62.8\end{array}$ & $\begin{array}{c}145 \\
100.0\end{array}$ \\
\hline University & $\begin{array}{l}\mathrm{N} \\
\%\end{array}$ & $\begin{array}{c}76 \\
52.1\end{array}$ & $\begin{array}{c}70 \\
47.9\end{array}$ & $\begin{array}{c}146 \\
100.0\end{array}$ \\
\hline Total & $\begin{array}{l}N \\
\%\end{array}$ & $\begin{array}{c}139 \\
38.6\end{array}$ & $\begin{array}{l}221 \\
61.4\end{array}$ & $\begin{array}{c}360 \\
100.0\end{array}$ \\
\hline \multicolumn{5}{|l|}{ Residence: } \\
\hline Town & $\begin{array}{l}\mathrm{N} \\
\%\end{array}$ & $\begin{array}{c}108 \\
41.7\end{array}$ & $\begin{array}{c}151 \\
58.3\end{array}$ & $\begin{array}{c}259 \\
100.0\end{array}$ \\
\hline Village & $\begin{array}{l}\mathrm{N} \\
\%\end{array}$ & $\begin{array}{c}32 \\
31.3\end{array}$ & $\begin{array}{c}69 \\
68.7\end{array}$ & $\begin{array}{c}101 \\
100.0\end{array}$ \\
\hline Total & $\begin{array}{l}N \\
\%\end{array}$ & $\begin{array}{c}140 \\
38.8\end{array}$ & $\begin{array}{l}220 \\
61.2\end{array}$ & $\begin{array}{c}360 \\
100.0\end{array}$ \\
\hline \multicolumn{5}{|l|}{ Parity: } \\
\hline Primipara & $\begin{array}{l}\mathrm{N} \\
\%\end{array}$ & $\begin{array}{c}95 \\
53.4\end{array}$ & $\begin{array}{c}83 \\
46.6\end{array}$ & $\begin{array}{c}178 \\
100.0\end{array}$ \\
\hline $\begin{array}{l}\text { Secun- } \\
\text { dipara }\end{array}$ & $\begin{array}{l}\mathrm{N} \\
\%\end{array}$ & $\begin{array}{c}36 \\
24.7\end{array}$ & $\begin{array}{c}110 \\
75.3\end{array}$ & $\begin{array}{c}146 \\
100.0\end{array}$ \\
\hline Multipara & $\begin{array}{l}N \\
\%\end{array}$ & $\begin{array}{c}8 \\
22.2\end{array}$ & $\begin{array}{c}28 \\
77.8\end{array}$ & $\begin{array}{c}36 \\
100.0\end{array}$ \\
\hline Total & $\begin{array}{l}N \\
\%\end{array}$ & $\begin{array}{c}139 \\
38.6\end{array}$ & $\begin{array}{l}221 \\
61.4\end{array}$ & $\begin{array}{c}360 \\
100.0\end{array}$ \\
\hline
\end{tabular}

* Row percentages presented

According to the respondents' reports, the content of the courses was focused mostly on labour and pain management, breastfeeding information, the postpartum period and infant care. About two-thirds (67\%) noted that the obtained information related to healthy lifestyle during pregnancy, and approximately half of them (57\%) received information about risk factors affecting healthy foetal development. None of the respondents mentioned any intervention for changing risk factors in the lifestyle. Nevertheless, the majority were satisfied with the lessons.
According to self-reported data, the majority of respondents $(85 \%)$ were informed about principal risk factors (Table 5 and 6). Their knowledge increased in proportion with educational level (Table 5); almost all differences in the frequency of correct answers between women with basic and university education were significant. Contact with a midwife during pregnancy (Table 6) seems to be very informative, but the imbalance in participation of women with different levels of education is an important confounding factor. The prevalence of those exposed to preventable risk factors was (inversely) associated with the level of education.

The most common source of information for $75 \%$ of respondents was the internet, $50 \%$ relied on their gynaecologist or special literature and $32 \%$ reported friends or mother as a source of information. A prenatal course provided information for $26 \%$ of the women. The lowest numbers of women listed school (6\%) or doula (3\%) as their information source. A majority of respondents $(80 \%)$ believed that information obtained during prenatal check-ups was sufficient for a healthy pregnancy.

Nearly all participants had been informed about cardinal risk factors: drug abuse, smoking (both active and passive), stress, excessive physical load, alcohol in any amount, high levels of caffeine and malnutrition (Table 5 and 6). A majority $(86 \%)$ of the respondents were aware of the positive impact of adequate physical activity during low risk pregnancy on both the mother's and infant's health. Unfortunately, $10 \%$ believed that physical activity has no impact and another $3 \%$ believed that physical activity positively influences only the mother's health while negatively affecting the infant's health; $1 \%$ was convinced that physical activity during pregnancy can have a negative impact on both mother and infant.

Regarding the questions about changes to a healthier lifestyle, more than half of the participants (56\%) thought they improved their diet in terms of quality and diversity, with $2.5 \%$ following a special medical diet. A majority consumed milk products (and occasional junk food) daily $(85 \%)$, favoured white meat $(75 \%)$, wholegrain bakery products (73\%) and vegetable oils (73\%) and ate at least 3 portions of fresh fruit (55\%) and fresh or steamed vegetables daily (58\%). Nearly three quarters $(73 \%)$ focused on healthy food shopping and prioritised better methods of cooking (boiling and stewing). Half (43\%) consumed fish at least once a week, but $33 \%$ stated frequent consumption of smoked meat products. Nearly one third (30\%) attained very good dietary habits (index: 8 to 10 points), and 6\% of respondents fulfilled all the main dietary recommendations. Nevertheless, one quarter $(25 \%)$ had an index value of 5 or less. About one third (31\%) modified habits before they became pregnant, and another $50 \%$ made positive changes during pregnancy. Some women (24\%) said that information received from a midwife was an impulse to improve their lifestyle.

A majority (83\%) reported multivitamin supplement consumption during the whole pregnancy; 38\% daily and $45 \%$ occasionally. Almost all of these women (75\%) had consulted with a professional about the vitamin supplementation. 
Table 5. Awareness of pregnant women of risk factors for healthy infant development (education).

\begin{tabular}{|c|c|c|c|c|c|c|c|}
\hline \multirow{3}{*}{$\begin{array}{l}\text { Risk factors } \\
\text { proportion of YES responses }\end{array}$} & \multicolumn{7}{|c|}{ Education } \\
\hline & \multicolumn{2}{|c|}{ Basic } & \multicolumn{2}{|c|}{ High school } & \multicolumn{2}{|c|}{ University } & \multirow{2}{*}{$\begin{array}{c}\text { Pearson's } \\
\text { x2 test } \\
\text { p-value }\end{array}$} \\
\hline & Count & Percent & Count & Percent & Count & Percent & \\
\hline Large or small weight gain in pregnancy & 35 & 55.6 & 76 & 56.3 & 97 & 70.8 & 0.024 \\
\hline Obesity of mother & 46 & 70.8 & 121 & 85.2 & 134 & 95.7 & $<0.001$ \\
\hline Malnutrition of mother & 57 & 86.4 & 139 & 97.2 & 138 & 97.2 & $<0.001$ \\
\hline Non-acceptance of pregnancy & 45 & 71.4 & 118 & 88.7 & 124 & 89.9 & $<0.001$ \\
\hline Smoking during pregnancy & 55 & 84.6 & 140 & 97.9 & 144 & 99.3 & $<0.001$ \\
\hline Partner's smoking at home & 46 & 73.0 & 126 & 90.6 & 142 & 98.6 & $<0.001$ \\
\hline Lack of physical activity & 38 & 60.3 & 88 & 64.7 & 109 & 82.0 & $<0.001$ \\
\hline Huge physical load & 55 & 83.3 & 130 & 92.9 & 133 & 95.7 & 0.008 \\
\hline Mother's negative emotions (anger, rage, fear) & 50 & 76.9 & 119 & 83.8 & 118 & 86.8 & 0.210 \\
\hline Mother's stress & 57 & 86.4 & 134 & 93.7 & 140 & 97.9 & 0.005 \\
\hline Reduction diet or non-consulted vegetarian diet & 37 & 56.1 & 130 & 93.5 & 134 & 95.0 & $<0.001$ \\
\hline Alcohol consumption (of any amount) & 57 & 86.4 & 134 & 94.4 & 121 & 88.3 & 0.105 \\
\hline Higher amount of coffee/caffeine & 50 & 76.9 & 122 & 87.8 & 120 & 89.6 & 0.042 \\
\hline Illegal drugs & 62 & 93.9 & 142 & 99.3 & 143 & 98.6 & 0.028 \\
\hline $\begin{array}{l}\text { Workload, including prolonged standing at work } \\
\text { (more than } 2 \text { hours) }\end{array}$ & 48 & 72.7 & 97 & 71.3 & 103 & 77.4 & 0.501 \\
\hline $\begin{array}{l}\text { Lack of knowledge about risks for infant's } \\
\text { development }\end{array}$ & 40 & 60.6 & 94 & 69.1 & 110 & 79.7 & 0.012 \\
\hline Lack of rest and sleep & 50 & 76.9 & 115 & 83.9 & 121 & 89.0 & 0.083 \\
\hline
\end{tabular}

Table 6. Awareness of pregnant women of risk factors for healthy infant development (contact with midwife).

\begin{tabular}{|c|c|c|c|c|c|}
\hline \multirow{3}{*}{$\begin{array}{l}\text { Risk factors } \\
\text { proportion of YES responses }\end{array}$} & \multicolumn{5}{|c|}{ Contact with midwife in course } \\
\hline & \multicolumn{2}{|c|}{ Yes } & \multicolumn{2}{|c|}{ No } & \multirow{2}{*}{$\begin{array}{c}\begin{array}{c}\text { Pearson's } \\
\text { x2 test }\end{array} \\
\text { p-value }\end{array}$} \\
\hline & Count & Percent & Count & Percent & \\
\hline Large or small weight gain in pregnancy & 87 & 62.6 & 121 & 54.8 & 0.309 \\
\hline Obesity of mother & 128 & 92.1 & 173 & 78.3 & 0.034 \\
\hline Malnutrition of mother & 139 & 100.0 & 195 & 88.2 & 0.012 \\
\hline Non-acceptance of pregnancy & 125 & 89.9 & 162 & 73.3 & 0.020 \\
\hline Smoking during pregnancy & 139 & 100.0 & 200 & 90.5 & $<0.001$ \\
\hline Partner's smoking at home & 136 & 97.8 & 178 & 80.5 & 0.019 \\
\hline Lack of physical activity & 104 & 78.2 & 131 & 59.3 & 0.015 \\
\hline Huge physical load & 134 & 94.4 & 184 & 83.3 & 0.205 \\
\hline Mother's negative emotions (anger, rage, fear) & 126 & 89.4 & 161 & 72.9 & 0.017 \\
\hline Mother's stress & 139 & 100.0 & 192 & 86.9 & 0.031 \\
\hline Reduction diet or non-consulted vegetarian diet & 128 & 90.8 & 173 & 78.3 & 0.083 \\
\hline Alcohol consumption (of any amount) & 131 & 92.3 & 181 & 81.9 & 0.337 \\
\hline Higher amount of coffee/caffeine & 125 & 89.3 & 167 & 75.6 & 0.192 \\
\hline Illegal drugs & 139 & 100.0 & 208 & 94.1 & 0.136 \\
\hline Workload, including prolonged standing at work (more than 2 hours) & 101 & 75.4 & 147 & 66.5 & 0.647 \\
\hline Lack of knowledge about risks for infant's development & 103 & 74.6 & 141 & 63.8 & 0.331 \\
\hline Lack of rest and sleep & 122 & 89.7 & 164 & 74.2 & 0.033 \\
\hline
\end{tabular}


Inadequate physical activity was a typical phenomenon for most participants; $29 \%$ engaged in regular recommended levels before pregnancy; $55 \%$ participated in occasional physical activity; and 16\% admitted to "no physical activity". During pregnancy, 38\% of the women reduced their physical activity; $17 \%$ of respondents stated no change and kept good physical habits; $37 \%$ had no or insufficient physical activity and $8 \%$ enhanced their exercise activities in comparison with the situation before pregnancy.

Patterns of smoking were significantly influenced by educational level: $64 \%$ never smoked, out of which $78 \%$ were university educated women and $22 \%$ had a lower level of education ( $p<0.001$ ), while $6 \%$ kept smoking even during pregnancy (no university educated women continued to smoke); $4 \%$ of the non-smokers were exposed to passive smoking (Table 7 ). In the whole sample, $24 \%$ of foetuses were exposed to cigarette smoke for various lengths of time. These relationships were highly significant $(p<$
0.001), especially with long term lessons involving skill practice (Table 8 ). In this survey sample, no relationship was seen between smoking and medical problems during pregnancy and labour. Nearly $10 \%$ of respondents had abstained from alcohol throughout their lifetimes; the number of abstained has increased during pregnancy. Nearly $1 \%$ drank alcoholic beverages every day. The frequency of alcohol drinkers was significantly higher among university educated women. Neither prenatal lessons attendance nor parity influenced alcohol consumption. A majority (90\%) stated they had never tried any illegal drugs; $10 \%$ reported elimination of this habit before or during pregnancy (Table 7 ); and $2.5 \%$ of women declined to answer questions regarding drug consumption.

Some stress was very often experienced by $41 \%$ of women at the beginning of pregnancy, by $19 \%$ during the whole pregnancy and by nearly one half (44\%) before labour. Medium and very high levels of stress were experienced by

Table 7. Most critical risk factors based on education level.

\begin{tabular}{|c|c|c|c|c|c|}
\hline \multirow[b]{2}{*}{ Risk factor (smoking, alcohol consumption, drugs) } & \multicolumn{5}{|c|}{ Education } \\
\hline & & Basic & High school & University & $\begin{array}{l}\text { Pearson's } x 2 \\
\text { test: } p \text {-value }\end{array}$ \\
\hline \multirow[t]{2}{*}{ Never smoked } & Count & 14 & 83 & 114 & \multirow{10}{*}{$<0.001$} \\
\hline & Percent & 20.6 & 59.7 & 78.1 & \\
\hline \multirow[t]{2}{*}{ Gave up before pregnancy } & Count & 14 & 26 & 18 & \\
\hline & Percent & 20.6 & 18.7 & 12.3 & \\
\hline \multirow[t]{2}{*}{ Gave up during pregnancy } & Count & 19 & 20 & 11 & \\
\hline & Percent & 27.9 & 14.4 & 7.5 & \\
\hline \multirow[t]{2}{*}{ Current smoker (even during pregnancy) } & Count & 16 & 4 & 0 & \\
\hline & Percent & 23.5 & 2.9 & 0.0 & \\
\hline \multirow[t]{2}{*}{ Passive smoking during pregnancy } & Count & 5 & 6 & 3 & \\
\hline & Percent & 7.4 & 4.3 & 2.1 & \\
\hline \multirow[t]{2}{*}{ Never drank alcohol } & Count & 11 & 10 & 6 & \multirow{8}{*}{0.017} \\
\hline & Percent & 16.4 & 7.0 & 4.1 & \\
\hline \multirow[t]{2}{*}{ Gave up before pregnancy } & Count & 42 & 88 & 86 & \\
\hline & Percent & 62.7 & 62.0 & 58.9 & \\
\hline \multirow[t]{2}{*}{ Occasionally during pregnancy } & Count & 14 & 44 & 52 & \\
\hline & Percent & 20.9 & 31.0 & 35.6 & \\
\hline \multirow[t]{2}{*}{ Current alcohol consumption (even during pregnancy) } & Count & 0 & 0 & 2 & \\
\hline & Percent & 0.0 & 0.0 & 1.4 & \\
\hline \multirow[t]{2}{*}{ Never tried illicit drugs } & Count & 57 & 130 & 129 & \multirow{8}{*}{0.117} \\
\hline & Percent & 87.7 & 92.9 & 88.4 & \\
\hline \multirow[t]{2}{*}{ Gave up before pregnancy } & Count & 6 & 9 & 17 & \\
\hline & Percent & 9.2 & 6.4 & 11.6 & \\
\hline \multirow[t]{2}{*}{ Gave up during pregnancy } & Count & 2 & 1 & 0 & \\
\hline & Percent & 3.1 & 0.7 & 0.0 & \\
\hline \multirow[t]{2}{*}{ Occasionally during pregnancy } & Count & 0 & 0 & 0 & \\
\hline & Percent & 0.0 & 0.0 & 0.0 & \\
\hline
\end{tabular}

* Column percentages presented 
$60 \%$ of those reporting stress. No stress during pregnancy was reported by $19 \%$. To cope with stress, one third of women used daily relaxation techniques including psychohygienic prevention and stress management, and another $50 \%$ used these methods occasionally. Participation in prenatal courses had a statistically insignificant effect on stress before labour (Table 8).

Table 8. Influence of prenatal course on lifestyle during pregnancy. information and skills were related to labour. Since women must pay for course participation, opportunities for this specialised education may be limited or inaccessible for the unemployed or economically-challenged. In our study, determining factors for prenatal course participation were primiparity, previous contact with a midwife and holding a university degree. These conditions result in health education and prenatal behaviour. Women with lower education had poorer health literacy (knowledge and habits)

\begin{tabular}{|c|c|c|c|c|c|c|}
\hline \multirow[b]{2}{*}{ Item } & & \multicolumn{5}{|c|}{ Participation in prenatal course: } \\
\hline & & None & One lesson & $\begin{array}{l}\text { Theoretical } \\
\text { lessons }\end{array}$ & $\begin{array}{l}\text { Whole } \\
\text { course }\end{array}$ & Total \\
\hline \multirow[t]{3}{*}{ Average index of dietary habit } & $\mathrm{N}$ & 221 & 24 & 29 & 86 & 360 \\
\hline & Mean & 6.19 & 6.67 & 6.38 & 7.27 & 6.49 \\
\hline & Std. Deviation & 1.99 & 1.66 & 1.59 & 1.79 & 1.94 \\
\hline \multirow[t]{3}{*}{ Index of dietary habit* } & Poor & 54.5 & 33.3 & 41.7 & 25.5 & 44.9 \\
\hline & Good & 45.5 & 66.7 & 58.3 & 74.5 & 55.1 \\
\hline & Total & 100.0 & 100.0 & 100.0 & 100.0 & 100.0 \\
\hline \multirow[t]{4}{*}{ Change of physical activity* } & The same & 51.0 & 47.8 & 53.8 & 42.2 & 48.8 \\
\hline & Reduced & 45.0 & 30.4 & 42.3 & 37.3 & 41.9 \\
\hline & Enhanced & 4.0 & 21.7 & 3.8 & 20.5 & 9.3 \\
\hline & Total & 100.0 & 100.0 & 100.0 & 100.0 & 100.0 \\
\hline \multirow[t]{5}{*}{ Smoking* } & Never or quit during planning & 69.4 & 75.0 & 89.7 & 89.3 & 76.2 \\
\hline & Quit during pregnancy & 18.5 & 8.3 & 6.9 & 7.1 & 14.2 \\
\hline & Still smoking (or smoking & & & & & \\
\hline & environment) & 12.0 & 16.7 & 3.4 & 3.6 & 9.6 \\
\hline & Total & 100.0 & 100.0 & 100.0 & 100.0 & 100.0 \\
\hline \multirow[t]{3}{*}{ Alcohol* } & No & 70.8 & 62.5 & 58.6 & 67.4 & 68.5 \\
\hline & Yes & 29.2 & 37.5 & 41.4 & 32.6 & 31.5 \\
\hline & Total & 100.0 & 100.0 & 100.0 & 100.0 & 100.0 \\
\hline \multirow{4}{*}{$\begin{array}{l}\text { Stress reduction techniques } \\
\text { change* }^{*}\end{array}$} & Yes, before the pregnancy & 16.3 & 17.4 & 22.2 & 30.5 & 20.2 \\
\hline & Yes, during the pregnancy & 40.2 & 47.8 & 33.3 & 37.8 & 39.6 \\
\hline & No & 43.5 & 34.8 & 44.4 & 31.7 & 40.2 \\
\hline & Total & 100.0 & 100.0 & 100.0 & 100.0 & 100.0 \\
\hline
\end{tabular}

* Column percentages presented

\section{DISCUSSION}

Pregnancy is a very important time for both the mother and the child. A well-planned pregnancy should consider optimal timing according to parental age, health condition, mental maturity, supporting social environment and acceptance of recommendations for healthy lifestyle with necessary supplementation (25). Many contemporary women feel that physical observations by an obstetrician alone are insufficient care and some of them ask for prenatal education that will help them to be prepared for labour and parenthood $(26,27)$. The best course curriculum should also involve educational lessons, effective interventions for lifestyle change, training methods for coping with stress and anxiety and useful skills during delivery and postnatal care of newborns and infants. Such complex subjects should be prepared by professionals, comprehensively unified and presented by midwives upon completion of their certification. The content of prenatal courses is not yet unified in the Czech Republic and in many other countries. Our study indicates that the largest amount of available and participated in prenatal courses less often. The most frequent sources of information are mass media and the internet. This should be a signal for health educators to monitor the accuracy of the information available on the internet and to motivate less educated women to attend prenatal courses.

In our entire sample, nearly all of the participants were well informed about critical health risk factors for mother and child: smoking, alcohol, drugs and stress. The knowledge index value increased with higher education and long-term midwife contact in a course, but not with prenatal obstetrician visits. Despite this knowledge, one quarter of the respondents were exposed actively or passively to cigarette smoke during pregnancy. Those women were more frequently less educated and involved with a smoking family. As such exposure represents important risks for pregnancy and the foetus, comprehensive anti-smoking education and intervention must be focused on this vulnerable group of women: younger, less educated with lower social status and low social support, without a partner or with a smoking partner, with many children, living with 
stress, experiencing life trauma and lacking love in their lives (28). These conditions restrict access to socially acceptable dopamine resources, minimising participation in pleasant daily events, and these women tend, therefore, to smoke significantly more often during pregnancy (29). Intervention should be oriented towards fathers as well, since their smoking is a source of environmental toxins and can initiate hereditary malformations and reproduction malfunctions (30).

In contrast to pregnant smokers, women consuming alcohol during pregnancy are more often older (>35 years), multiparas and with higher educational levels and socio-economic status (31). Our study confirmed these data. Neither visiting prenatal courses nor parity were significant determinants for alcohol consumption during pregnancy. The most significant determinant was the level of education.

In our sample, knowledge about dietary recommendations and nutritional habits were not optimal. Concordant with foreign studies (32), the obese respondents were usually less educated and smoked. The majority obtained no individual recommendation during early pregnancy for optimal weight gain, although high entry BMI value negatively influences the woman's health and the pregnancy with a higher risk of hypertension, gestational diabetes, preeclampsia, prolonged pregnancy, macrosomia and late foetal death, Caesarean delivery, infectious complications in the postnatal period and obesity and diabetes for both mother and child. It is important to note that imperfect maternal nutrition can be a risk factor even during preimplantation and placental development $(33,34)$.

We found that age, parity and experience from a previous pregnancy are significant predictors of prenatal stress and anxiety, so very young and less educated primiparas and multiparas with traumatic experiences are at a higher risk of stress, even when their actual pregnancy is physiological. Although the current health care model is not sufficiently developed to identify these at-risk women (35), participation in prenatal lectures during our study reduced the number of anxious mothers before labour. A lower incidence of stress was identified in the group of higher-educated women.

The results of a US study showed that many family doctors and obstetricians are not familiar with the latest recommendations for physical activity during pregnancy. Many women reduce their physical activity during pregnancy, especially in the third trimester when they consider passive relaxation and rest to be more important $(36,37)$. In our study, the quality of physical activity was higher within the group of highly educated women, findings similar to those of a Swiss survey (38), but in general, exercise during pregnancy did not correspond with the current recommendations for optimal levels.

Special education and training for midwives in consulting, intervention methods and skill training is essential, as it can be the best way for them to become valuable sources of information, motivation and support (39). In the Czech Republic, most prenatal courses are provided by midwives (with certification from the regular educational state system), but they can be provided by almost anybody who arranges a business certificate for educational activities, which can be obtained without any proof of professional qualifications at the Trade Office. In our sample, only one third $(32 \%)$ were in long-term contact with a midwife in prenatal courses. These participants reported that they were better prepared overall for labour and birth and felt less stressed at the end of pregnancy; more of them opted for breastfeeding. The feeling of readiness for labour and birth proportionally increased with the length of contact with a midwife, initiated through the women's higher knowledge index value and higher degree of education. These enlightened and well-educated women clearly stated that the information provided to them by midwives helped them to manage the postnatal period, and that they plan to be in contact with midwives during future pregnancies.

A serious limitation of our study is the selection of the subgroup of pregnant women who decided to participate in prenatal courses: the majority of them were university educated and thus of higher social strata. Due to this selection, we were able to describe determinants of their knowledge, behaviour and attendance but not to clearly assess the influence of prenatal courses on pregnancy, labour and early maternal care for newborns. We think it possible that economic barriers are the main reason for this selection, as lectures are offered as paid services, above standard secondary prevention.

\section{CONCLUSION}

Our results from the sample of pregnant women in the Czech Republic confirmed previously published data noting that health literacy and healthier lifestyle of pregnant women are associated with a higher level of education and long-term contact with a midwife in prenatal courses. Professional intervention and advice on primary prevention topics are necessary in order to achieve the goals of decreasing smoking, alcohol consumption and bad nutritional habits and improving support and skills for coping with stress. Therefore, we recommend improving and unifying the content of prenatal lessons, reviewing lecturers' qualifications and establishing economic conditions that permit all women to participate in prenatal educational programs free of charge with the support of public health insurance companies.

\section{CONFLICT OF INTEREST}

The authors declare that no conflict of interest exist.

\section{FUNDING}

The study had no accessional financial support.

\section{ETHICAL APPROVAL}

Received from the Ethical Committee of Medical Faculty and University Hospital, Masaryk University, Brno. 


\section{REFERENCES}

1. Tremblay J, Hamet P. Impact of genetic and epidemic factors from early life to later disease. Metabolism 2008; 57: 27-31.

2. Lillycrop K, Burdge G. Epigenetic mechanisms linking early nutrition to long term health. Best Pract Res Clin Endocrinol Metab 2012; 26: 667-76.

3. Barker D. The developmental origins of adult disease. J Am Coll Nutr 2004; 23: 588-95.

4. Giussani DA, Camm EJ, Niu Y, Richter HG, Blanco CE, Gottschalk R. et al. Developmental programming of cardiovascular dysfunction by prenatal hypoxia and oxidative stress. PLoS One 2013; 7: e31017.

5. Ministry of Health, Czech Republic. Národní strategie ochrany a podpory zdraví a prevence nemocí - Zdraví 2020. Available February 12, 2013 from: http://www.uzis.cz/category/tematicke-rady/zdravotnickastatistika/rodicka.

6. Jones S, Telenta J, Shorten A, Johnson K. Midwives and pregnant women talk about alcohol: what advice do we give and what do they receive? Midwifery 2011; 27: 489-96.

7. Reynolds J. Fetal alcohol spectrum disorders: gene-environment interactions, predictive biomarkers, and the relationship between structural alterations in the brain and functional outcomes. Semin Pediatr Neurol 2011; 18: 49-55.

8. Loprinzi P, Fitzgerald E, Cardinal B. Physical activity and depression symptoms among pregnant women from the national health and nutrition examination survey 2005-2006. J Obstet Gynecol Neonatal Nurs 2012; 41: 227-35.

9. Demissie Z. Physical activity and depressive symptoms among pregnant women: the PIN3 study. Arch Women's Mental Health 2011; 14: 145-57.

10. Moos M. Prenatal care: limitations and opportunities. J Obstet Gynecol Neonatal Nurs 2006; 35: 278-85.

11. Ickovits J. Group prenatal care and preterm birth weight: results from a matched cohort study at public clinics. Obstet Gynaecol 2003; 102: 1051-7.

12. Berglund A. Consequences of programme changes in antenatal care. Comprehensive summaries of Uppsala dissertations from the Faculty of Medicine 1990; 888.

13. Hobel C, Goldstein A, Barret E. Psychosocial stress and pregnancy outcome. Clin Obstet Gynecol 2008; 51: 333-48.

14. Chen $M$. The use of psychological stress scales in preterm birth research. Am J Obstet Gynecol 2011; 205: 402-34.

15. Valero De Bernabé J, Soriano T, Albaladejo R, Juarranz M, Calle ME, Martínez D. et al. Risk factors for low birth weight: a review. Eur $\mathrm{J}$ Obstet Gynecol Reprod Biol 2004; 116: 3-15.

16. Středa L, Maradova E, Zima T. Vybrané kapitoly o zdravi. Prague: Univerzita Karlova, 2010.

17. Lu M. Preventing low birth weight: is prenatal care the answer? J Matern Fetal Neonatal Med 2003; 13: 362-80.

18. Koehn M. Contemporary women's perceptions of childbirth education. J Perinat Educ 2008; 17: 11-8.

19. Ngai FW, Chan SW, Ip WJ. The effects of a childbirth psychoeducation program on learned resourcefulness, maternal role competence and perinatal depression. Int J Nurs Stud 2009; 46: 1298-306.
20. Consonni EB, Calderon IM, Consonni M, De Conti MH, Prevedel TT, Rudge MV. A multidisciplinary program of preparation for childbirth and motherhood: maternal anxiety and perinatal outcomes. Reprod Health 2010; 29: 7-28.

21. Beldon A. Health promotion in pregnancy: the role of the midwife. J R Soc Promot Health 2005; 125: 216-20.

22. Holčik J. Systém péče o zdravi a zdravotni gramotnost. Brno: Masarykova univerzita, 2010.

23. Pender NJ. Heath promotion model: manual. c2011. 18 p. Available January 82012 from: http://deepblue.lib.umich.edu/bitstream/handle/2027.42/85350/HEALTH_PROMOTION_ MANUAL_Rev_5-2011. pdf?sequence $=1$.

24. Kukla L, Hrubá $D$, Tyrlík M. Průběh těhotenství a vývoj plodu u kouřících a nekouřících žen. Čes Gynek 1999; 64: 271-4.

25. Barrett G, Wellings K. What is a planned pregnancy? Empirical data from British study. Soc Sci Med 2002; 55: 545-57.

26. Loureiro MI, Goes AR, da Cámara GP, Gonçalves-Pereira M, Maia T, Saboga Nunes L. Priorities for mental health promotion during pregnancy and infancy in primary health care. Glob Health Promot 2009; 16: 29-38.

27. Prochaska JM, Mauriello L, Dyment S, Gökbayrak S. Designing a health behavior change program for dissemination to underserved pregnant women. Public Health Nurs 2011; 28: 548-55.

28. Ashford K. The effects of prenatal secondhand smoke exposure on preterm birth and neonatal outcomes. J Obstet Gynecol Neonat Nurs 2010; 39: 525-35.

29. Schneider S, Schütz J. Who smokes during pregnancy?: a systematic literature review of population-based surveys conducted in developed countries between 1997 and 2006. Eur J Contracept Reproduct Health Care 2008; 13: 138-47.

30. Hrubá D. Riziko kouřeni v těhotenstvi se stále podceňuje: tolerovat kouřeni v těhotenstvi je neodborné a neetické. Prakt Gyn 2011; 15: 2-7.

31. Skagerström J, Chang G, Nilsen P. Predictors of drinking during pregnancy: a systematic review. J Womens Health 2011; 20: 901-13.

32. Kaiser L, Allen L. Position of the American dietetic association: nutrition and lifestyle for a healthy pregnancy outcome. J Am Diet Assoc 2008; 108: 553-61.

33. Cnattingius S. Prepregnancy weight and the risk of adverse pregnancy outcomes. N Engl J Med 1998; 338: 147-52.

34. Wu G, Imhoff-Kunsch B, Webb-Girard A. Biological mechanism for nutritional regulation of maternal health and fetal development. Paediatr Perinat Epidemiol 2012; 26: 4-26.

35. Lynn F. Associations between maternal characteristics and pregnancyrelated stress among low-risk mothers: an observational cross-sectional study. Int J Nurs Stud 2011; 48: 620-7.

36. Benelam B. Physical activity in pregnancy. Nutr Bull 2011; 36: 370-2.

37. Gaston A, Vamos $\mathrm{CH}$. Leisure-time physical activity patterns and correlates among pregnant women in Ontario, Canada. Matern Child Health J 2013; 17: 477-84.

38. Evenson K, Bradley $\mathrm{CH}$. Beliefs about exercise and physical activity among pregnant women. Patient Educ Couns 2010; 79: 124-9.

39. Fenwick J. Women's perceptions of emotional support following childbirth: a qualitative investigation. Midwifery 2013; 29: 217-24. 